\title{
An Empirical Study on the Relationship between Chinese Interest Rate and Stock Price
}

\author{
Xiaojiao Ye \\ School of Economics \\ International Business school \\ Yunnan University of Finance and Economics \\ Yunnan, China \\ 997463214@qq.com
}

\author{
Ziling Huang* \\ International Business school \\ Yunnan University of Finance and Economics \\ Yunnan, China \\ 690271098@qq.com
}

\begin{abstract}
As economy and society improves rapidly, the strength of a country is inseparable from the development of the financial industry. As an important regulatory tool for monetary policy, the interest rate level affects investors' demand for stocks, and on the other hand, it reflects the fluctuations in the stock prices that affect listed companies.
\end{abstract}

The main aim is to study the relationship between interest rate changes and stock price. First of all, from theoretical perspective, reviewing the factors that affect the stock price fluctuations. Then, analyzing the effect of interest rate changes on stock price through a great number of literature references. Finally, empirical studies are conducted through quantitative research to discuss the correlation between Chinese stock and interest markets.

The conclusion indicates that there is a positive correlation between stock prices and interest rates in the short term. In the long term, interest rates and stock prices express a negative relation, which is consistent with the previous research results. Compared with the development trend of foreign stock markets, the stock market in China is not standardized and effective. Therefore, the study concludes with some suggestions for improving the effectiveness of the stock market.

Keywords-interest rate; Ock price; relationship

\section{INTRODUCTION}

As one of the important components of financial market, the financial industry has affected the future trend of the economy and society. Chinese stock market with the establishment of the securities market is gradually developed from the initial 10 listed companies to 3341 listed companies in mid-2017, Chinese financial market is growing fast and powerful and has developed more mature. The interest rate market has played an indispensable role in the financial market. When the market information of the interest rate market changes, the stock price is able to make a corresponding response to the extent that the stock price at this time is valid, and financial markets are also stabilizing.

*Corresponding author
The emergence and development of Chinese stock market has only taken less than 20 years. The improvement of stock market in China and the increasing number of listed companies can represent this situation; on the other hand, it is reflected in the improvement and function of a series of stock market systems represented by margin financing, stock index futures, Shanghai-Hong Kong Stock Connect, and stock index options. Completely on. It has almost finished the development of the stock market of western developed countries for more than 200 years, which is the result of brilliant reform. The current market structure, or the efficiency of the clearing system, even the size of the market, is hardly far from the stock market in many western countries. Yu proposed that the adjustment of financial policies by the People's Bank of China was conducive to maintaining financial stability and economic growth. Therefore, monetary policy has become one of the important factors which can affect the stock market in China. And the interest rate becomes one of the important monetary policy tools and it is an essential mean for central bank to adjust the market economy [20].

The overall research aim is to make a study of the correlation of Chinese interest rate and stock price and find out whether the correlation is positive or negative. The empirical analysis of the relation between Chinese stock and interest rate can be concluded with short-term and long-term effects. According to the analysis and research results, the ultimate purpose is to obtain the predicted change trend through the correlation between these two aspects.

First, explaining the factors which affect the stock prices of listed companies. This is the starting point of the whole study and the overall grasp of interest market and the listed companies. Second, analyzing the correlation between Chinese interest rate and stock price through literature review and theoretical analysis. The core content of this study examines the reasons, modalities and levels about how interest rate affects stock prices. Third, discussing the interest rate market on the long-term and short-term impact of the stock price of listed companies. It made an important conclusion through the integration of the two effects for the entire study. Finally, expressing the empirical analysis of the correlation between Chinese stock and interest market. 
Foreign researches on the relationship between interest market and the stock prices commenced very early. Affected by national conditions, Chinese scholars started late in this field, and they have always been based on the study of foreign scholars, from the perspective of having Chinese characteristics. Cut in and study the correlation between these two.

Hamburger and Kochin discussed that the money supply had an important direct effect on the stock market in the shortterm, but the influence was independent of the currency's impact on interest rates [9]. Roley and Sellon [10], Radecki and Reinhart [15], and Kuttner [17] used the simple linear regression method, respectively, to study effects of adjustment of the federal funds' target interest rate on the yield of government bonds in 1987-1995, 1989-1992 and 1989-200, but found very inconspicuous results. In the macro market, Li [14] conducted an empirical research of the impact of interest adjustment on the Shanghai securities market. The results showed that, whether it was in the short run or long run, interest rate adjustment had no significant effect on the trading volume of the Shanghai Stock Exchange [14].

These scholars believe that the relationship between the two is not obvious. However, some scholars believe that there is a clear correlation between the two.

Cook and Hahn [3] used the simple linear regression method to analyze the effect of the change in the interest rate from 1974 to 1979 on the yield of government bonds. It was found that every $1 \%$ increase in the target interest rate of the federal fund would cause the Yields to have risen by 55 basis points and the yield on the 30-year government bond has only risen by 10 basis points. $\mathrm{Li}$ [13] believed that there was a positive correlation between government bond interest and stock markets, but the result was not absolute. When there was a stock market crisis, the bond interest rate and stock price were negatively correlated.

Alireza and Strauss [1] researched the impact of interest rates on share prices in the market by using cointegration tests and found the change of stock prices and interest rate moved in the same direction in the short run. But stock prices and interest rates moved in the opposite direction in the long run. Tu [19] showed that there was a clear negative correlation between stock market and interest adjustments in the short term through a large number of empirical analysis, that was interest rates will fall, and vice versa.

A large number of scholars have conducted in studies on the relation between interest rate and stock prices. In the early years of study on the relationship between these two, the situation in different countries in the world was different. The sample data years also had different sample ages, which led to many conclusions that were inconsistent and even opposite.

\section{FACTORS AfECTING STOCK PRICES}

The factors that affect stock prices mainly include two major internal and external factors. Internal factors of the company are reflected in the company's own factors and market factors.
First of all, the self-value of stock is the most basic factor in determining the stock index and this mainly depends on the profitability, operating level, the level of creditworthiness, and the dividend distribution status, development prospects, stock expected return level and so on. The trends of investors, the intention and manipulation of large companies, speculators' arbitrage behavior and the company's capital increasing methods and so on may all contribute to the formation of stock price.

The external factors of the enterprise mainly include industry factors and economic factors. Changes in the status of the industry in the national economy, the development trends and potential of the industry and the position of listed companies in the industry, profitability and operating conditions and so on will affect the price of the relevant stocks. Changes in the macro-environment, financial policies, and adjustments in the country's exchange rates will all affect the changes in the stock price.

\section{SAMPLING}

Because it needs to analyze effects of interest rates on the stock price of listed companies in the short-term and long-term, all need to analyze and filter the interest rate data. This study is decided after considering a lot of literature review. The original data were collected mainly from the People's Bank of China and the stock software. Since October 2017, it has been searching for information and analysis to provide sufficient time and basis for further research. The research method is mainly empirical research and quantitative analysis.

The Chinese stock market chose the data from 2006 to 2017 because the establishment time was relatively short and short while the financial listed company's stock price used the sample data of the Shanghai Stock Exchange Index. the specific data of the Shanghai financial index of the variable data and test data and the interest rates in recent ten years should be obtained. For the short-term effect analysis, selected the adjusted interest rates from 2007 to 2016 as the sample, and the stock price sample is the Shanghai Stock Index interest rate adjustment date of the closing price as its share price.

For the long-term effect analysis, the interest rate sample took the 30-month interbank offered rate from January 2007 to December 2016 and took the original sequence value. The data mainly comes from stock software and the official website of the People's Bank of China, www.pbc.gov.cn.

\section{EMPIRICAL ANALYSIS}

The influence of changes in interest rate on stock prices in the end will be very large, and the results of domestic and foreign scholars are not the same. Some scholars believed that stock price was not sensitive to changes in interest rate, and that changes in interest rates did not have much influence on stocks in China. Durham [6] researched the relation between interest rates, stock returns and treasury yields of the U.S. federal funds. The results showed that the adjustment of interest rates had an impact on the yield of government bonds and had little effect on the return on stocks. And in China, some scholars believe that the relationship between the two is 
not obvious. Dong and Liu [5] analyzed the impact of the People's Bank of Chinese raising interest rate on stock prices and concluded that the actual performance of Chinese capital markets on the People's Bank of Chinese raising interest rate did not support the theory that rising interest rates would lead to a drop in the stock price of listed companies. The rise and fall of the stock market is not a simple negative correlation, but a comprehensive analysis by the actual conditions behind the specific monetary policy. Wang analyzed the impact of various interest rate adjustments of the People's Bank of China on stock market from 1996 to 2002, and stated that from May 1, 1996 to February 21, 2002, the People's Bank of China successively cut interest rates and generated Inertia plays an essential role in establishing the scale of capital market. And then Friedman [8] used the VAR model and found that the stock price was positively correlated with lagging M2 in the three quarters through the study of the US market data from 1961 to 1986. The same-direction change means that the income effect is greater than the substitution effect.

However, most scholars believe this view is incorrect. First, there is a time lag between interest rate adjustments and changes in stock prices. A downward adjustment in interest rates can lead to savings diversion and increasing the supply of money in the stock market can cause changes in stock prices. Therefore, the fluctuation of the stock price on interest rate adjustment day or the next trading day cannot fully reflect the influence of the interest rate adjustment on the stock market. Second, interest rate adjustments are predictable, and information on interest rate adjustments may also be revealed in advance. Therefore, stock price fluctuations before the official announcement of interest rate cuts are also worth noting. Again, there are many causes of stock price volatility, and interest rates are just one of many factors that cause stock price volatility. Finally, the relation between these two is not a certain one.

This study selected data from twenty-four interest rate adjustments from 2006 to 2017 to perform multiple linear regression analysis. According to these 24 interest rate adjustments and the corresponding closing prices of the stocks, a line chart can be made to see the relationship between the two.

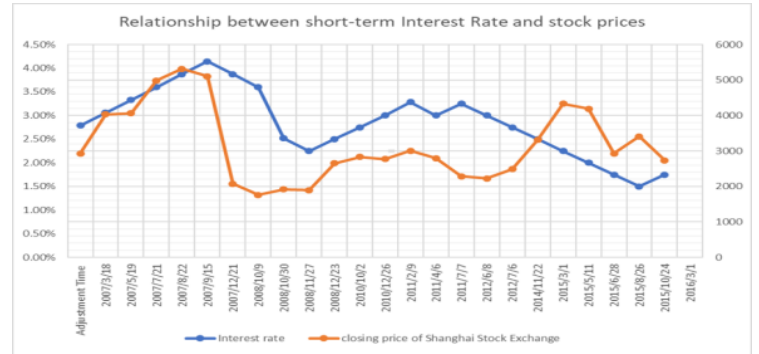

Fig. 1. Relationship between Short-term Interest Rate and Stock Prices

It can be seen from figure 1 that during the period from March 2007 to December 2010, the stock price rose with the increase of interest rate. While the interest rate declining, the stock price also fell, that is, the stock price and interest rate Changes in direction, which are contrary to theoretically negative correlations. From 2003 to October 2008, the trend curve of interest rates and stock prices basically coincided with a slight upward trend. From October 2008 to December 2010, although interest rates and stock prices have moved in the same direction, the stock price curve is steeper than the interest rate curve. In fact, the stock price was falling with interest rate in 2008. From 5,000 points to 2,000 points. During the period from December 2010 to June 2012, the Shanghai Composite Index fell with the increase of interest rates, and the negative correlation with the theory was consistent at this time. At the same time, with several changes from 2014 to 2016, stock prices have generally risen as interest rates have fallen.

In general, during the period from 2007 to 2016, the rate of change in interest rates was relatively small, while the stock prices fluctuated. It can be seen that many factors will make the changes of stock market. And the interest rate is just the one of these factors. It cannot just rely on changes in interest rates to obtain changes in stock prices. Sometimes the changes in the stock market are even contrary to the theoretical results. Luo and Chen [12] found the effects of the eight interest rate cuts on the stock market after 1996 and found that the announcement of interest rate policies showed irregularities in the volatility of the stock price on the first trading day. Pearce \& Rowley [4] mainly examined the short-term impact of the announcement of the US money supply change from 1977 to 1982 on the stock price. The conclusion was consistent with the effective market hypothesis. It was considered that investors were based on the macro economy. The situation has long been expected to cut interest rates.

The specific empirical analysis of the short-term impact is mainly based on the data regression model analysis.

First, the average of the 7-day daily change of the Shanghai Stock Price Index before the interest rate adjustment is taken as one of the independent variables. This is because it can represent the historical price of the Shanghai Stock Exchange Index in the short-term. At the same time, the rate of change in the interest rate level appears as another independent variable. From this, a regression analysis model can be designed, such as the equation:

$$
\mathrm{Y}=\alpha+\beta_{1} I+\beta_{2} \Delta r+\varepsilon
$$

In this equation, $\mathrm{Y}$ is $\log$ return of average Shanghai Stock Index of 7 transaction date after the adjustment of interest rate. I represents log return of average Shanghai Stock Index of 7 transaction date before the adjustment of interest rate. $\Delta r$ represents the range of interest rate adjustment. $\varepsilon$ represents the other influencing factors.

Through the analysis of the above model, it can be seen that the magnitude $\mathrm{Y}$ is using as the overall dependent variable, the interest rate adjustment rate and the log return of average Shanghai Stock Exchange's 7 transactions before the interest rate adjustment I are considered as independent variable. The logarithmic return index $\mathrm{I}=\operatorname{Ln} P_{t}-\operatorname{Ln} P_{t-1}$ is used as an independent variable, and these data are subjected to regression analysis according to the formula model that has been designed. 


\begin{tabular}{|c|c|c|c|c|}
\hline Variable & Coefficient & Std.Error & t-Statistic & Prob. \\
\hline $\mathrm{C}$ & 0.004344 & 0.001681 & 2.584986 & 0.0177 \\
\hline $\mathrm{I}$ & 0.350105 & 0.15127 & 2.314445 & 0.0314 \\
\hline$\Delta \mathrm{r}$ & 0.000732 & 0.004932 & 0.148405 & 0.8835 \\
\hline
\end{tabular}

Fig. 2. Short-term aalysis of the rgression model

From the results of table 1 can be obtained by the following formula:

$$
\mathrm{Y}=0.004344+0.350105 \mathrm{I}+0.000732 \Delta \mathrm{r}+\varepsilon
$$

This regression model represents the influence of interest rate changes on stock prices and correlation between them in the short term. From the results of regression analysis, the stock price index is positively correlated with the money supply, and the correlation coefficient is relatively weak, but it has certain statistical significance.

In the long-term empirical analysis, the correlation between the two is firstly analyzed by using the stock price and interest rate data to make a line chart.

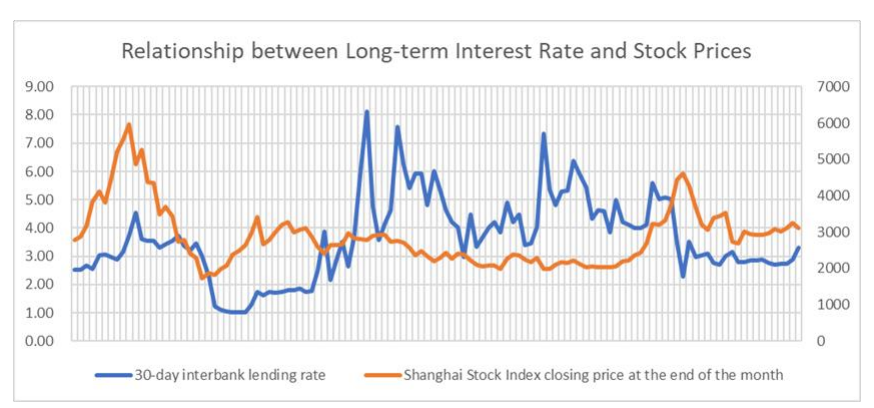

Fig. 3. Relationship between Long-term interest rte and sock pices

As can be seen from figure 2, in most of the periods, interest rates and stock prices show an inverse relationship. Then, there may be spurious regressions between variables, so a smoothness test is required. The purpose of using the ADF test is to check if the interest rate sequence and the stock price sequence are stable and operational. The ADF test is based on the interest rate selected in this article and the stock price of the Shanghai Securities Finance Index. The result is as follows:

\begin{tabular}{|c|c|c|c|}
\hline & & t-Statistic & Prob. $^{*}$ \\
\hline $\begin{array}{c}\text { Augmented Dickey- } \\
\text { Fuller test statistic }\end{array}$ & & -2.017918 & 0.2789 \\
\hline Test Critical Values: & $1 \%$ level & -3.486053 & \\
\hline & $5 \%$ level & -2.885849 & \\
\hline & $10 \%$ level & -2.579858 & \\
\hline
\end{tabular}

Fig. 4. ADF satistic of iterest rte tme series

According to the analysis of table 2, the ADF statistic of the interest rate series is greater than $10 \%$ of the significant level as a $\mathrm{T}$ statistic, and the interest rate time series is a non-stationary sequence.

\begin{tabular}{|c|c|c|c|}
\hline & & t-Statistic & Prob. $^{*}$ \\
\hline $\begin{array}{c}\text { Augmented Dickey- } \\
\text { Fuller test statistic }\end{array}$ & & -10.12517 & 0.0000 \\
\hline Test Critical Values: & $1 \%$ level & -3.486551 & \\
\hline & $5 \%$ level & -2.886074 & \\
\hline & $10 \%$ level & -2.579931 & \\
\hline
\end{tabular}

Fig. 5. ADF satistic of the frst-order dfference squence of Interest rate series
Based on the test results of table 3, the ADF statistic of the first-order difference sequence of interest rate series is less than at the significant level of $10 \%$ as the T statistic, and the firstorder difference sequence of interest rate time series is a stationary sequence.

\begin{tabular}{|c|c|c|c|}
\hline & & t-Statistic & Prob. $^{*}$ \\
\hline $\begin{array}{c}\text { Augmented Dickey- } \\
\text { Fuller test statistic }\end{array}$ & & -3.486932 & 0.01 \\
\hline Test Critical Values: & $1 \%$ level & -3.486064 & \\
\hline & $5 \%$ level & -2.885863 & \\
\hline & $10 \%$ level & -2.579818 & \\
\hline
\end{tabular}

Fig. 6. ADF Statistic of Exponential Sequence

From the above test results of table 4, the ADF statistic of the exponential sequence is less than the $1 \%$ statistical significance $\mathrm{T}$ statistic, and the index time series is a stationary sequence. Through the above analysis, the next step is to analyze the cointegration relation between the interest rate and the stock price.

Cointegration analysis can be performed after the ADF test. Then using the Johansen maximum likelihood method to analyze the cointegration relationship between these two variables.

\begin{tabular}{|c|c|c|c|c|}
\hline $\begin{array}{c}\text { Hypothesized } \\
\text { No.of CE(s) }\end{array}$ & Eigenvalue & $\begin{array}{c}\text { Trace } \\
\text { Statistic }\end{array}$ & $\begin{array}{c}0.05 \\
\text { Critical Value }\end{array}$ & Prob. $^{* *}$ \\
\hline None & 0.099828 & 15.19171 & 15.49471 & 0.0455 \\
\hline At most 1 & 0.026573 & 3.097279 & 3.841466 & 0.0784 \\
\hline
\end{tabular}

Fig. 7. The Cointegration Relationship based on Johansen maximum likelihood method

The hypothesis for correlation between the interest rate and stock prices.

: Interest rate has positive effect on stock price.

: Interest rate does not have positive effect on stock price.

Thus, according to table 5 , it can be seen that $\mathrm{P}$ value is 0.455 and less than 0.5 , then eigenvalue statistics reject the null hypothesis .It means that the interest rate does not have positive effect on stock price.

At the same time, from this measurement, it can be seen that the 30-day interbank borrowings interest rate and stock price have a cointegration relationship at a 5\% confidence level. The Johansen cointegration vector estimation method used here can be concluded as a simple linear relationship by using the data of the 30-day interbank borrowings interest rate and stock price in these ten years.

$$
\mathrm{I}=4.5921-0.0003 \mathrm{R}+\varepsilon
$$

I represents stock price and $\mathrm{R}$ represents the 30-day interbank borrowings interest rate. $\varepsilon$ represents the other influencing factors. From the results of the cointegration test, there is an equilibrium relationship between the interest rate and the stock prices in the long-term, and this analysis shows that the correlation is negatively correlated. When the interest rate falls, the stock price is rising. Therefore, using the error correction model (EMC) to test the correlation between these two in order to explain the effect of long-term equilibrium on 
the short-term fluctuations based on the co-integration test. So, using Eviews8.0 to make an error correction model, the final empirical test regression yields the following results:

\begin{tabular}{|c|c|c|c|c|}
\hline Variable & Coefficient & Std. Error & t-Statistic & Prob. \\
\hline $\mathrm{C}$ & 0.008524 & 0.077584 & 0.109867 & 0.9127 \\
\hline $\mathrm{D}(\mathrm{I}(-1))$ & -0.053107 & 0.094322 & -0.563041 & 0.5745 \\
\hline $\mathrm{D}(\mathrm{R}(-1))$ & $6.35 \mathrm{E}-05$ & 0.000258 & 0.246202 & 0.806 \\
\hline $\mathrm{U}(-1)$ & -0.176145 & 0.058114 & -3.031037 & 0.003 \\
\hline
\end{tabular}

Fig. 8. Empirical text regression based on ECM

Through the analysis of table 6 , the model formula is obtained as:

$\mathrm{I}=0.008524-0.053107 \mathrm{I}(-1)-6.3533 \mathrm{E}-05 \mathrm{R}(-1)-0.176145 \mathrm{ECM}(-1)$

From the model estimation, it can be seen that the interest rate of the interbank borrowing will make the stock price change in the opposite direction, the ECM at this time is less than zero, and the purpose of using this model is to restore its equilibrium level that can play a role in error correction, this is why the ECM is used to analyze the data.

From the empirical results of the co-integration relationship, it can be seen that there is a stable co-integration relationship in the long run between the interest rate and stock prices. It can be seen that there is a negative correlation between the 30-day interbank borrowing rate $\mathrm{R}$ and the Shanghai Securities Financial Index I. When the interest rate changes by 1 point, the SSE Financial Index will change -6.3533E-05. In other words, both the interbank borrowing rate and the SSE Financial Index are in opposite directions. This conclusion is also basically consistent with previous theoretical analysis.

In general, interest rates and financial listed companies stock prices interact and affect each other. Li and Jiang [11] found the correlation between the money and stock market in the 1990s. The results showed that there was a causal relationship between stock prices and money supply in the long run. Benink and Wolff [2] studied the relation between the stock return and interest rate of banking industry in America. It was concluded that there was a negative correlation between the interest rate and the interest rate volatility of interest rate derivatives. Whether in the short-term or long-term, changes in direction would affect the stock prices of financial listed companies.

\section{CONCLUSION}

After extensive literature analysis, it can be concluded that there is an undeterminable relationship between stock prices and interest rate markets. Sprinkel [18] used an intuitive graph analysis to empirically analyze the correlation between money supply and stock markets. The study found that changes in the money supply would make movements in stock market. The peak in stock price movements lags behind about 15 money supplies. In the month, the bottom value lags about 2 months. However, Rigobon and Sack [16] found that the United States S \& P 500 index in the short term with the adjustment of interest rates was in the opposite direction. The difference in these conclusions comes from different variable choices, time factors, model methods, and so on.
By empirically analyzing the effects of interest rates on the stock prices of listed companies in the short run and long run, the following conclusions can be drawn.

First of all, it can be seen that in the short run changes in the Shanghai securities price index and interest rates show a positive relationship according to the short-term analysis. From the output, it can be seen that when the interest rate rises by 0.000732 , the Shanghai financial index will rise by one point. It can be seen that the influence of changes in interest rates in the short-term on the Shanghai financial index is actually not significant.

Secondly, the changes in the interest rates and the Shanghai Stock Exchange Index in China have shown a long-term cointegration relationship and the prices and interest rates of the Shanghai Securities Financial Index have changed in opposite directions. Fama [7] used cointegration test to study the correlation between the yield of securities in America and longterm interest rates, that is, there is an equilibrium relationship between stock prices and long-term interest rates. Therefore, the equilibrium effect of interest rates on stock prices is unquestionable in the long run.

In addition to the current process of interest rate liberalization in China, interest rates have not yet been fully marketized. The formulation of interest rate policies does not adequately reflect the overall market conditions. Therefore, even if the interest rates are adjusted in the short term, other variables in the financial market will not necessarily change with it.

\section{ACKNOWLEDGEMENTS}

During this period of writing the study, I would like to thank my supervisor, I will thank the scholars in the reference literature. According to analyzing their researches, my study becomes more complete and meaningful. Furthermore, I would also like to express my thanks to my parents and classmates for their encouragement and support in the process of finishing the study. Finally, I offer my sincere thanks again.

\section{REFERENCES}

[1] N. Alireza, and J. Strauss, "Stock Prices and Domestic and International Macroeconomic Activity: A Cointegration Approach". The quarterly review on economics and finance, Vol.2,2000, pp.229-245.

[2] H. Benink, and C. Wolff, C. "Survey Data and the Interest Rate Sensitivity of US Bank Stock Returns". Economic Notes.Vol.1, pp.201213,8th July 2000

[3] Cook, Timothy and Thomas Hahn. "The Effect of Changes in the Federal Funds Rate Target on Market Interest Rates in 1970s". Journal of Monetary Economics, Vol.2,1989, pp.331-351.

[4] K. Douglas, Pearce. and V. Vance Roley. "The Reaction of Stock Prices to Unanticipated Changes in Money: A note". Journal of Finance, American Finance Association, Vol.4,1983, pp.1323-1333.

[5] Dong Peiwu and Liu Feng "Analysis of the Impact of Interest Rate Changes on Stock Price". Modern Business Industry, Vol.7,2008, pp.197-198.

[6] B. Durham, Does Monetary Policy Affect Stock Prices and Treasury Yields? An Error correction and simultaneous equation approach, Federal Reserve Working Paper,2003.

[7] Fama, Schwert. "The behavior of stock market prices". Journal of Business, Vol.2,1990, pp.34-105. 
[8] A. Friedman. Schwartz. "Money and the Stock Market". Journal of Political Economy, Vol.2,1988, pp.77-86.

[9] M. Hamburger. and L. Kochin. "Money and Stock Prices: The Channels of Influences". Journal of Finance, Vol.4,1972, pp.231-249.

[10] K.N. Kuttner, "Monetary Policy Surprises and Interest Rates : Evidence from Fed Funds Futures Market". Journal of Monetary Economics, Vol.,47, 2001, pp.523-544.

[11] Li Hongyan and Jiang Tao "An Empirical Analysis of the Relationship between Stock Prices and Money Supply in Chinese Stock Market". Prediction, Vol.3,2000, pp.37-40.

[12] Luo Chenyu and Chen Yu "Analysis of Short-term and Long-term Effect of Interest Rate Policy on Chinese Stock Market". Financial Science, Vol.1,2002, pp.96-97.

[13] Li L "The Correlation of Stock and Bond Returns : Theory and Empirical Evidence”. Yale Working Paper, Vol.5,2002, pp.32-58.

[14] Li Zhengyi "Analysis of the Impact of Interest Rate Changes on Stock Price". Statistics and Decision, Vol.2,2002, pp.12-13.

[15] L. Radecki, and V. Reinhart.The Financial Linkages in the Transmissionof Monetary Policy in the United States Bank for International Settlements Basel,1994.
[16] R. Rigobon, and B. Sack. "Measuring the Reaction of Monetary Policy to the Stock Market". Quarterly journal of economics, Vol.2,2001, pp.639-669, Science direct [Online]. Available at:

http://trove.nla.gov.au/work/73952666?q\&versionId=87144953(Accesse d: $21^{\text {st }}$ May 2003)

[17] V.V. Roley, and Sellon, G.H. "Monetary Policy Actions and Long-Term Interest Rate". Federal Reserve Bank of Kansas City Economic Quarterly, Vol.80,1995, pp.77-89.

[18] Sprinkel.B.W. Money and Stock Prices. Homewood. Richard D. Irwin, 1964.

[19] Tu Xiaomin "Analysis of the Impact of Interest Rate Adjustment on Chinese Stock Market". Journal of Southwest University for Nationalities, Vol.3,2005, pp.236-238.

[20] Yu Chen "Research on the Relationship between Interest Rate and Stock Price Index in China". Science and Technology Pioneering Monthly, Vol.10, pp.23-25, 2007. 